\title{
AMERICAN
}

ANTIQUITY

VOLUME 28

NUMBER 4

APRIL 1963

PUBLISHED BY THE SOCIETY FOR AMERICAN ARCHAEOLOGY 


\section{OFFICERS OF THE SOCIETY FOR AMERICAN ARCHAEOLOGY}

President: David A. BAERreIs, Department of Anthropology, Sterling Hall, University of Wisconsin, Madison 6, Wis.

President-Elect: JAMES A. Ford, American Museum of Natural History, Central Park West at 79 th Street, New York 24, N.Y.

Secretary: JoE BEN WheAT, University of Colorado Museum, Boulder, Colo.

Treasurer: ALFRED KIDDER II, The University Museum, University of Pennsylvania, 33rd and Spruce Sts., Philadelphia 4, Pa.

Editor: T. N. CAMPBELL, Department of Anthropology, University of Texas, Austin 12, Tex.

Executive Committee Members: J. L. Giddngs (to 1963), Haffenreffer Museum, Mount Hope Grant, Brown University, Bristol, R. I.; HenRY W. Hamitron (to 1964), 537 Eastwood, Marshall, Mo.; BetTy J. Meggers (to 1964), U.S. National Museum, Washington 25, D.C.; Douglas W. Schwartz (to 1963), Museum of Anthropology, University of Kentucky, Lexington, Ky.

\section{EDITORIAL STAFF OF AMERICAN ANTIQUITY}

Editor: T. N. Camprell, Department of Anthropology, University of Texas, Austin 12, Tex.

Associate Editor: E. Mort Davis, Department of Anthropology, University of Texas, Austin 12, Tex.

Associate Editor for Reviews: RoBERT E. BELL, Department of Anthropology, University of Oklahoma, Norman, Okla.

Associate Editor for Current Research: Charles E. Borden, Department of Anthropology and Sociology, Division of Archaeology, University of British Columbia, Vancouver 8, B. C.

Assistant Editors for Current Research: ARCTIC - JoHn M. CAMPBelL, Department of Sociology and Anthropology, George Washington University, Washington 6, D.C., CALIFORNIA - FraNCIS A. RrdDEll, History Section, State Division of Beaches and Parks, Box 2390, Sacramento 11, Calif.; CARRIBBEAN - Patrick Gallagher, Department of Sociology and Anthropology, George Washington University, Washington 6, D.C.; CENTRAI AMERICA - WolfGang HaberL.AND, Hamburgisches Museum für Völkerkunde und Vorgeschichte, Binderstrasse 14, Hamburg 13, Germany; EASTERN MESOAMERICA - WILLIAM R. COE, The University Museum, University of Pennsylvania, 33rd and Spruce Sts., Philadelphia 4, Pa.; GREAT BASIN-WullaM J. WalLACE, Department of Anthropology, University of Southern California, Los Angeles 7, Calif.; HIGHLAND SOUTH AMERICA - EDwARd P. LANNing, Huamanga 151, Magdalena Nueva, Lima, Peru; LOWLAND SOUTH AMERICA - BetTy J. Megcers, U. S. National Museum, Washington 25, D. C.; NORTHEAST - JoHN L. Corter, Region Five, National Park Service, 143 South 3rd St., Philadelphia 6, Pa.; NORTHERN MISSISSIPPI VALLEY - WARREN L. Wrrrry, Cranbrook Institute of Science, Bloomfield Hills, Mich.; NORTHWEST Ruchard D. Daugherty, Department of Sociology and Anthropology, Washington State University, Pullman, Wash.; PLAINS - RoberT L. StEPHenson, River Basin Surveys, 1517 O Street, Lincoln 8, Neb.; SOUTHEAST - HeSTRR A. DAvis, University of Arkansas Museum, Fayetteville, Ark.; SOUTHWEST - Alfred E. Jornson, Arizona State Museum, University of Arizona, Tucson, Ariz.; WESTERN MESOAMERICA - JoHN PADDock, Department of Anthropology, Mexico City College, Km. 16 Carretera México-Toluca, México 10, D. F.

Editorial Assistant: LoReng G. Camprell, 3210 Bonnie Road, Austin 3, Tex.

Americain ANTIRUITY publishes original papers on the archaeology of the New World and closely related subjects. Articles and "Facts and Comments" should be submitted to the Editor, publications for review to the Associate Editor for Reviews, and information for "Curtent Research" to the appropriate Assistant Editor for Current Research. Contributors to AMERICAN ANTIQUITY should consult "Information for Authors," last published in Vol. 28, No. 4, 1963, pp. 603-4. AmErICAN ANTIRUITY is not available for exchange.

Amerrcan Antrourty is published quarterly in July, October, January, and April by the Society for American Archaeology at the University of Utah Press, Salt Lake City 12, Utah. Entered as secondclass matter June 1, 1951, at the Post Office, Salt Lake City, Utah, under the Act of March 3, 1879. Subscription is by membership in the Society for American Archaeology; annual dues are $\$ 8.00$, of which $\$ 7.00$ are for a subscription to AMERICAN ANTiQuiry and other regular publications of the Society as issued. Address requests for membership or other information to the Secretary. Send instructions for change of address to Society for American Archaeology, 1530 P Street, N.W., Washington 5, D. C. See inside back cover for information on ordering back issues of AMERICAN ANTIQUITY and other publications of the Society which are still in print. 